\title{
PENGARUH CORPORATION RISK DAN GOOD CORPORATE GOVERNANCE TERHADAP TAX AVOIDANCE DENGAN KEPEMILIKAN INSTITUSIONAL SEBAGAI VARIABLE PEMODERASI
}

\author{
Tryas Chasbiandani ${ }^{1}$, Triastuti $^{2}$, Sri Ambarwati ${ }^{3}$ \\ ${ }^{1,2,3}$ Fakultas Ekonomi dan Bisnis, Universitas Pancasila, Jl. Raya Lenteng Agung No.56- \\ 80, RT.1/RW.3, Srengseng Sawah, Jagakarsa Kota Jakarta Selatan, Daerah Khusus \\ Ibukota Jakarta 12640, Indonesia \\ e-mail:tryas@univpancasila.ac.id
}

\begin{abstract}
Tax avoidance measured by Earning Tax Rate (ETR) is considered to be able to describe the real activities of tax avoidance carried out by the company. The purpose of this study was to analyze the effect of Corporation Risk and Good Corporate Governance on Tax Avoidance with Institutional Ownership as a Moderating Variable. This study uses a sample of non-banking and financial companies listed on the Indonesia Stock Exchange for the period of 2014-2016. The analysis in this study uses the common effect method. The results of this study indicate that corporate risk does not significantly influence tax avoidance, but with institutional ownership as a moderating variable, corporate risk has a significant effect on corporate tax avoidance. Corporate governance as measured by institutional ownership, board of commissioners and audit quality has a significant effect on tax company avoidance.
\end{abstract}

Keywords: Tax avoidance, Corporate Risk, Corporate governance, institutional ownhership, board of commisioner dan audit quality

\begin{abstract}
ABSTRAK
Tax avoidance yang diukur berdasarkan Earning Tax Rate (ETR) dianggap mampu menggambarkan aktivitas nyata dari tax avoidance yang dilakukan oleh perusahaan. Tujuan dari penelitian ini adalah untuk menganalisis pengaruh Corporation Risk dan Good Corporate Governance Terhadap Tax Avoidance dengan Kepemilikan Institusional Sebagai Variable pemoderasi. Penelitian ini menggunakan sampel perusahaan non perbankan dan keuangan yang terdaftar di Bursa Efek Indonesia periode 2014 - 2016. Analisis dalam penelitian ini menggunakan metode common effect. Hasil dari penelitian ini menunjukkan bahwa corporate risk tidak berpengaruh secara signifikan terhadap tax avoidance, namun dengan kepemilikan institusional sebagai variabel pemoderasi, corporate risk berpengaruh signifikan terhadap tax avoidance perusahaan.Corporate governance yang diukur dengan kepemilikan institusional, dewan komisaris dan kualitas audit berpengaruh signifikan terhadap tax avoidance perusahaan.
\end{abstract}

Kata kunci: Tax avoidance, Corporate Risk, Corporate governance, kepemilikan institusional, dewan komisaris dan kualita audit 


\section{PENDAHULUAN}

Indonesia merupakan negara berkembang dimana sumber pendanaan yang paling besar bagi pembangunan nasional berasal dari sumber daya alam dan pembayaran pajak. Sumber pendapatan harus ditingkatkan secara optimal agar pelaksanaan pembangunan dapat berjalan dengan baik untuk mewujudkan kesejahteraan masyarakati. Untuk itu diharapkan kepatuhan wajib pajak dalam menjalankan kewajiban perpajakannya secara sukarela sesuai dengan peraturan perpajakan yang berlaku. Waluyo (2011) menyatakan bahwa kemandirian suatu bangsa atau negara salah satunya adalah dalam pembiayaan berupa pembayaran pajak. Wajib pajak badan (perusahaan) berusaha untuk membayar pajak serendah karena pajak dianggap sebagai sesuatu yang membebani dan mengurangi pendapatan atau laba bersih perusahaan, sedangkan pemerintah menginginkan pajak setinggi mungkin guna membiayai penyelenggaraan pemerintahan. Perusahaan sebagai wajib pajak badan cenderung mencari cara untuk mengurangi jumlah pembayaran pajak baik secara legal maupun illegal. Usaha pengurangan pembayaran pajak secara legal disebut penghindaran pajak (tax avoidance), sedangkan usaha pengurangan pembayaran pajak secara illegal disebut tax evasion.

Selain perusahaan dituntut untuk membayar pajak, perusahaan go public di Indonesia juga diharuskan untuk menerapkan corporate governance. Corporate governance merupakan tata kelola perusahaan yang menentukan arah kinerja perusahaan (Maharani dan Suardana, 2014). Baik buruknya tata kelola perusahaan dapat tercermin dari kepemilikan institusional, kepemilikan manajerial, dewan komisaris independen, komite audit dan kualitas audit yang dapat mempengaruhi suatu perusahaan yang berkaitan dengan pembayaran pajak penghasilan perusahaan. Komisaris independen adalah anggota Dewan Komisaris yang berasal dari luar perusahaan yang tidak memiliki hubungan afiliasi dengan direksi atau dewan komisaris serta tidak menjabat sebagai direktur pada suatu perusahaan yang terkait dengan perusahaan pemilik serta bebas dari hubungan bisnis untuk bertindak independen, diharapkan menjamin transparansi dan keterbukaan laporan keuangan perusahaan sehingga memenuhi kepatuhan pada perundang-undangan pajak yang berlaku sehingga diharapkan tidak melakukan tax avoidance.

Pemimpin perusahaan biasanya memiliki dua karakter yaitu, risk taker dan risk averse yang tercermin pada besar kecilnya risiko perusahaan yang ada. Semakin tinggi risiko suatu perusahaan, maka eksekutif cenderung bersifat risk taker, dimana perusahaan cenderung menghindari pajak. Sebaliknya, semakin rendah resiko suatu perusahaan, maka eksekutif cenderung bersifat risk averse, cenderung melakukan pembayaran pajak. Karakteristik perusahaan adalah ciri khas suatu entitas usaha, yang dapat menjadi salah satu faktor penentu dalam tindakan penghindaran pajak (tax avoidance). Menurut Dewi dan Jati (2014), semakin besar ukuran perusahaan mengindikasikan semakin besar total assetnya, dimana perusahaan melakukan transaksi yang semakin kompleks, memungkinkan perusahaan untuk memanfaatkan cela-cela yang ada untuk melakukan tidakan penghindaran pajak dari setiap transaksi. Objek penelitian ini dilakukan pada perusahaan manufaktur yang terdaftar pada Bursa Efek Indonesia periode 2014 2017. Perusahaan-perusahaan manufaktur terbuka adalah merupakan salah satu industri di BEI yang relatif berkembang dan aktif dalam perdagangan saham.

\section{6}

Chasbiandani' ${ }^{1}$, Triastuti², Ambarwati ${ }^{3}$ 


\section{TINJAUAN PUSTAKA DAN PENGEMBANGAN HIPOTESIS Pengaruh Corporate Risk (Risiko Perusahaan) Terhadap Tax Avoidance}

Perusahaan dengan corporate risk tinggi atau risk taker cenderung akan melakukan tax avoidance. Eksekutif yang mempunyai sifat risk taker tidak akan takut ketika membuat keputusan yang beresiko tinggi. Semakin berani eksekutif melakukan resiko maka semakin tinggi eksekutif tersebut melakukan tax avoidance. Coles at al., (2004) menyebutkan risiko perusahaan ialah cerminan dari kebijakan yang diambil oleh pimpinan perusahaan sehingga dapat memberikan indikasi karakter eksekutif risk taking atau risk averse. Apabila dikaitkan dengan karakter eksekutif, karakter eksekutif risk averse akan cenderung takut untuk membuat keputusan melakukan pembiayaan hutang karena mereka akan lebih banyak menghindari risiko-risiko yang mungkin terjadi. Budiman dan Setiyono (2012) dan Dewi dan Jati (2014) menemukan adanya pengaruh antara karakteristik eksekutif dengan tax avoidance. Hal ini menandakan bahwa apabila eksekutif bersifat risk taker maka akan semakin besar pula tindakan tax avoidance yang dilakukan.Naik-turunnya risiko perusahaan mencerminkan kecenderungan dari karakter eksekutif.Penelitian Dyreng et al. (2010) mengenai pengaruh individu Top Executive terhadap penghindaran pajak perusahaan menyebutkan bahwa dalam melakukan penghindaran pajak perusahaan, individu memiliki peran yang sangat signifikan.

Struktur kepemilikan merupakan salah satu yang dapat mengurangi agency conflict. Struktur kepemilikan perusahaan juga dapat mempengaruhi besar kecilnya risiko perusahaan yang dapat terjadi. Khurana dan Moser (2009) mengungkapkan bahwa perusahaan dengan Kepemilikan Institusional yang besar dapat dikaitkan dengan tingkat agresivitas pajak yang dilakukan oleh perusahaan. Hasil penelitiannya membuktikan bahwa kepemilikan institusional berpengaruh signifikan positif terhadap tax avoidance. Semakin besarnya konsentrasi shortterm shareholder institusional akan meningkatkan kebijakan pajak agresif, tetapi semakin besar konsentrasi kepemilikan long-term shareholder maka akan semakin mengurangi tindakan kebijakan pajak yang agresif. Semakin baik struktur kepemilikan yang perusahaan memiliki, maka semakin kecil kemungkinan perusahaan menghadapi risiko. Hal tersebut karena tergantung kepada seberapa berani manajemen dalam mengambil risiko yang kemungkinan akan dihadapi di masa mendatang. Dengan kata lain, struktur kepemilikan akan dapat memperkuat pengaruh risiko perusahaan (corporate risk) terhadap tax avoidance. Berdasarkan pemaparan diatas maka hipotesis dalam penelitian ini adalah :

\section{$\mathrm{H}_{1}$ : Diduga Risiko Perusahaan (Karakter eksekutif) berpengaruh positif terhadap Tax Avoidance}

H2: Diduga Corporate Risk (Risiko Perusahaan) berpengaruh terhadap Tax Avoidance ketika dimoderasi oleh Struktur Kepemilikan Institusional.

\section{Pengaruh Kepemilikan Institusional Terhadap Tax Avoidance}

Kepemilikan institusional merupakan kepemilikan saham oleh pihak di luar perusahaan yang dimiliki oleh institusi seperti pemerintah, perusahaan investasi, bank dan investor luar negeri dapat membantu pihak prinsipal untuk mengontrol perilaku agen dalam perusahaan sehingga penghindaran pajak dapat 
diminimalisir. Diperlukan pengawasan dari pihak luar perusahaan untuk mengawasi pihak agen yang berperan penting dalam pengawasan kinerja manajemen yang lebih optimal karena mampu memonitor setiap keputusan yang diambil oleh para manajer. Semakin besar tingkat kepemilikan institusional perusahaan, maka semakin besar pula tingkat pengawasan terhadap manajer yang dapat mengurangi terjadinya penghindaran pajak.

Putranti dan Setiawanta (2015) serta Merslythalia dan Lasmana (2016) dalam penelitiannya menyatakan semakin besar kepemilikan saham oleh investor maka semakin kuat investor untuk mendesak manajer untuk bertindak Yoanis Carrica Wijayanti dan Ni Ketut Lely A. Merkusiwati. Pengaruh... 708 sesuai dengan tujuan investor dan tidak mementingkan dirinya sendiri.Oleh karena itu, dari penelitian terdahulu disimpulkan bahwa kepemilikan institusional berpengaruh negatif pada penghindaran pajak. Berdasarkan hal tersebut, maka hipotesis yang dapat dirumuskan dalam penelitian ini adalah.

\section{$\mathrm{H}_{3}$ : Kepemilikan institusional berpengaruh negatif terhadap Tax Avoidance}

\section{Pengaruh Komisaris Independen Terhadap Tax Avoidance}

Tugas komisaris independen dalam memastikan prinsip-prinsip dan praktik GCG dipatuhi dan diterapkan dengan baik, antara lain menjamin transparansi dan keterbukaan laporan keuangan perusahaan, kepatuhan perusahaan pada perundang-undangan dan peraturan yang berlaku, serta menjamin akuntanbilitas program perseroan (Effendi,2016:36). Maharani dan Suardana (2014) serta Diantari dan Ulupui (2016) dalam penelitiannya bahwa proporsi komisaris independen berpengaruh negatif terhadap tax avoidance, hal ini berarti semakin besar proporsi komisaris independen dapat meningkatkan pengawasan, mengontrol dan mengendalikan pihak manajemen untuk mencegah praktik tax avoidance. Berdasarkan uraian di atas maka penelitian ini mengajukan hipotesis sebagai berikut:

\section{$\mathrm{H}_{4}$ : Komisaris Independen berpengaruh negative terhadap Tax Avoidance.}

\section{Pengaruh Kualitas Audit Terhadap Tax Avoidance}

Sandy dan Lukviarman (2015) serta Fadhilah (2014) diperoleh hasil bahwa kualitas audit berpengaruh negatif terhadap terhadap tax avoidance. Kualitas audit yang diproksikan dengan ukuran KAP, dimana KAP besar (Big Four Accounting Firm) diyakini dapat melakukan audit yang lebih berkualitas dikarenakan KAP BigFour memberikan banyak pelatihan dan diakui secara internasional, serta memberikan audit yang berkualitas guna memberikan laporan keuangan yang berkualitas untuk melindungi reputasi nama KAP. Perusahaan yang diaudit oleh KAP BigFour akan memiliki tingkat kecurangan yang lebih rendah dibandingkan dengan perusahaan yang diaudit oleh KAP Non Big Four sehingga perusahaan terhindar dari penghindaran pajak. Hipotesis yang diuji dalam penelitian ini adalah :

\section{$\mathrm{H}_{5}$ : Kualitas audit berpengaruh negatif terhadap penghindaran pajak}

\section{8}




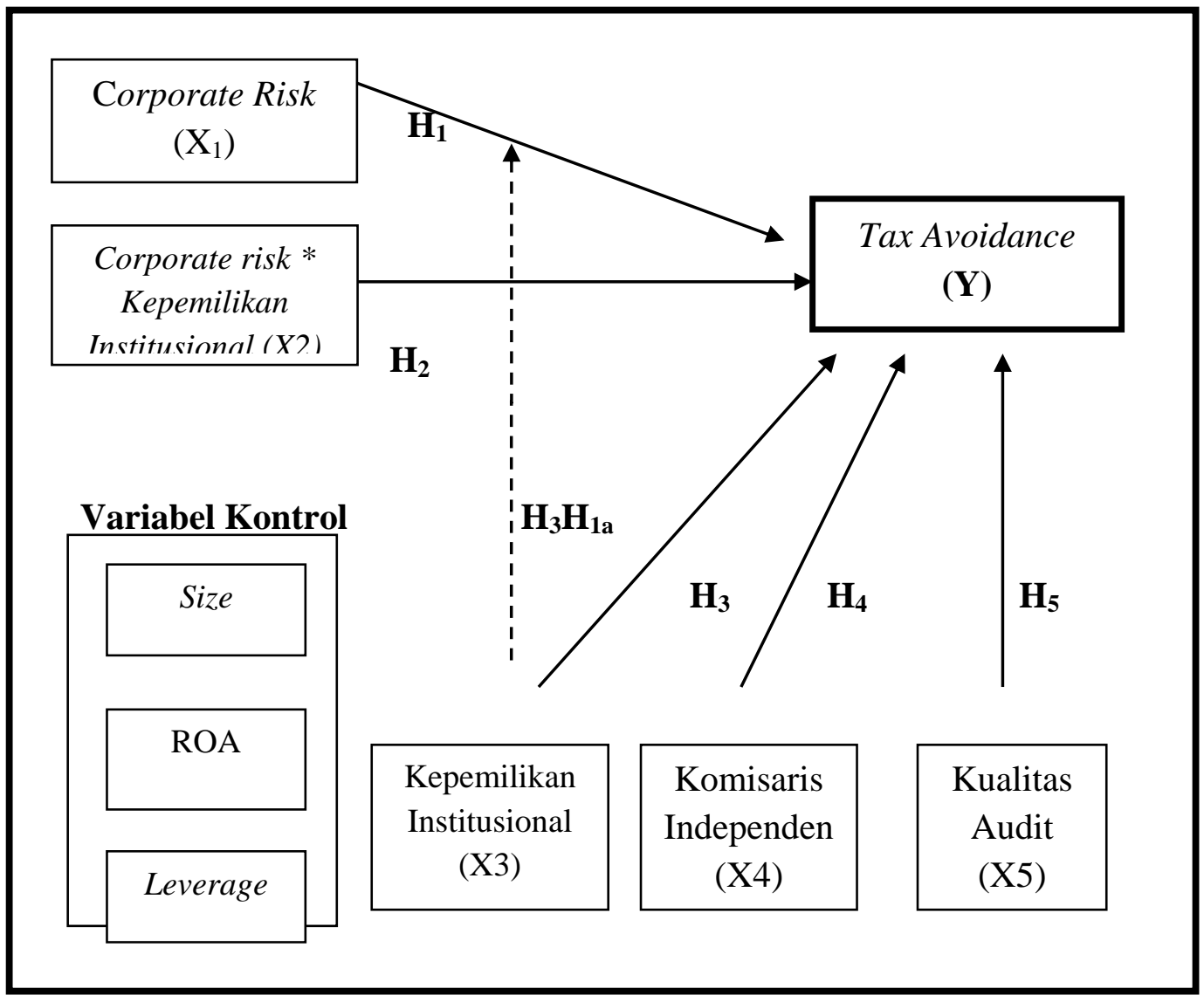

\section{Gambar 1. Kerangka Pemikiran}

\section{METODE PENELITIAN}

\section{Populasi dan Sample Penelitian}

Populasi sampel merupakan keseluruhan (universum) dari obyek penelitian yang dapat berupa manusia, hewan, tumbuh-tumbuhan, udara, gejala, nilai, peristiwa, sikap hidup dan sebagainya, sehingga obyek-obyek ini menjadi sumber data penelitian. Sampel adalah bagian dari jumlah dan karakteristik yang dimiliki populasi tersebut. Populasi dalam penelitian adalah Perusahaan Manufaktur yang terdaftar di Bursa Efek Indonesia dari tahun 2014-2016 yang menerbitkan laporan keuangan tahunan (annual report) dan diaudit dan dipublikasikan di Bursa Efek Indonesia (BEI) dengan mengkases situs resmi BEI yaitu www.idx.co.id.

Objek dalam penelitian ini adalah corporate risk, leverage, profitabilitas, size, komisaris independen, kepemilikan institusional, kualitas audit, serta tax avoidance pada perusahaan manufaktur yang terdaftar di Bursa Efek Indonesia. Penelitian ini menggunakan dua jenis data yaitu data kuantitatif dan kualitatif. Data kuantitaif yang digunakan dalam penelitian ini adalah laporan keuangan perusahaan manufaktur yang terdaftar di Bursa Efek Indonesia periode 2014- 
2017. Data kualitatif dalam penelitian ini berupa catatan atas laporan keuangan perusahaan.

\section{Teknik Pengambilan Sampel}

Teknik penentuan sampel yang digunakan adalah purpose sampling dimana penelitian ini tidak dilakukan pada seluruh populasi tetapi terfokus pada target atau cara pengambilan sampel berdasarkan kriteria/pertimbangan tertentu. Purpose judgement sampling adalah bahwa penentuan sampel mempertimbangkan kriteria-kriteria tertentu yang telah dibuat terhadap objek yang sesuai dengan tujuan penelitian. Adapun kriteria pemilihan sampel pada penelitian ini adalah sebagai berikut :

1. Perusahaan multinasional yang berada disektor manufaktur yang terdaftar di Bursa Efek Indonesia dan mempublikasikan laporan keuangan dari tahun 2014-2016.

2. Perusahaan manufaktur yang menyertakan laporan auditor independen bersama dengan laporan keuangan dan laporan tahunan yang telah diaudit pada periode 2014-2016.

3. Laporan keuangan tidak bermata uang asing.

4. Perusahaan multinasional sektor manufaktur yang tidak mengalami kerugian untuk periode yang berakhir pada 31 Desember dari tahun 2014-2016, dikarenakan kerugian akan mengakibatkan ETR menjadi negatif, sehingga Perusahaan memiliki ETR antara 0-1.

5. Laporan keuangan telah diaudit dengan pendapat wajar tanpa pengecualian.

\section{Operasionalisasi Variabel}

Variabel adalah objek penelitian atau apa yang menjadi titik perhatian suatu penelitian. Variabel dalam penelitian dibagi menjadi dua yaitu :

1. Variabel Independen (Variable Bebas $=X$ ) adalah variable yang mempengaruhi Variabel independen adalah variabel yang mempengaruhi atau menjadi sebabperubahannya atau timbulnya variabel dependen (terikat).

$$
\begin{aligned}
& \mathrm{X} 1=\text { Corporate Risk } \\
& \mathrm{X} 2=\text { Kepemilikan Institusional } \\
& \mathrm{X} 3=\text { Komisaris Independen } \\
& X 4=\text { Kualitas audit }
\end{aligned}
$$

2. Variabel Dependen (VariableTerikat/ Tidak Bebas $=\mathrm{Y}$ ), dalam penelitian iniadalah Penghindaran Pajak (Tax Avoidance) diukur dengan Effective Tax Rates (ETR).

3. Variabel moderasi adalah variabel independen yang akan memperkuat atau memperlemah hubungan antara variabel independen lainnya terhadap variabel dependen. Penelitian yang dilakukan oleh Giround dan Mueller (2011) menemukan bahwa tata kelola perusahaan yang lemah memiliki ROE yang rendah, kinerja operasi (ROA) yang buruk dan nilai perusahaan rendah. Dalam penelitian ini peneliti menggunakan corporate governance diproksikan dengan kepemilikan institusional sebagai variabel moderasi untuk menghubungkan antara variabel independen dan variabel dependen.

\section{0}




\section{Tabel 1 Operasionaliasi Variabel dan Skala Pengukuran}

Sumber : Diolah Sendiri

\begin{tabular}{|c|c|c|c|}
\hline Variabel & Indikator & Pengukuran & Skala \\
\hline $\begin{array}{l}\text { Tax Avoidance } \\
\text { (Y) }\end{array}$ & $\begin{array}{l}\text { Effective Tax } \\
\text { ratio }\end{array}$ & $E T R=\frac{\text { beban pajak penghasilan }}{\text { total laba sebelum pajak }}$ & Rasio \\
\hline $\begin{array}{c}\text { Risiko Perusahaan } \\
\text { (corporate risk) } \\
\left(\mathrm{X}_{1}\right)\end{array}$ & Risk & Risk $=\frac{E B I T D A}{\text { TotalAsetPerusahaan }}$ & Rasio \\
\hline Size & Size & Size $=$ Ln Total Aktiva & Nominal \\
\hline Profitability & Return On Asset & $R O A=\frac{\text { Laba Bersih Setelah Pajak }}{\text { Total Aset }}$ & Rasio \\
\hline Leverage & DER & $\begin{array}{l}\text { DER } \\
=\frac{\text { Total Hutang Jangka Panjang }}{\text { Equity }}\end{array}$ & Rasio \\
\hline $\begin{array}{l}\text { Komisaris } \\
\text { Independen }\end{array}$ & KOMIND & $\begin{array}{l}\text { KOMIND } \\
=\frac{\sum \text { Saham institusional }}{\sum \text { Saham Beredar }}\end{array}$ & Rasio \\
\hline $\begin{array}{l}\text { Kepemilikan } \\
\text { Institusional }\end{array}$ & SKI & $\begin{array}{l}\text { Struktur Kepemilikan Institusional } \\
=\frac{\sum \text { Saham manajerial }}{\sum \text { Saham Beredar }}\end{array}$ & Rasio \\
\hline Kualitas Audit & KUALAUD & $\begin{array}{l}\text { Dengan menggunakan Dummy yaitu } \\
\text { mendapat nilai satu bila diaudit oleh } \\
\text { KAP Big Four dan mendapat nilai } \\
\text { nol jika tidak menggunakan jasa } \\
\text { KAP Big Four }\end{array}$ & Nominal \\
\hline
\end{tabular}

\section{Teknik Pengumpulan Data}

Jenis data yang digunakan dalam penelitian ini adalah data sekunder, Data sekunder merupakan sumber data yang diperoleh peneliti secara langsung melalui media perantara (diperoleh dan dicatat oleh pihak lain) berupa laporan keuangan perusahaan yang telah di audit dan catatan atas laporan keuangan perusahaan manufaktur yang terdaftar di Bursa Efek Indoneisa tahun 2014-2017 yang diambil dari Indonesia Capital Market Directory (ICMD) terbitan ECFIN (Institute for Economics and Financial Indonesia) mengenai data ikhtisar keuangan 
(performance summary), Indonesia Stock Exchange dengan mengakses website Bursa Efek Indonesia www.idx.co.id.

\section{Teknik Analisis Data.}

Teknik analisis data dalam penelitian ini menggunakan analisis regresi linier berganda dengan mengolah data menggunakan eviews versi 9.Teknik analisis yang digunakan dalam penelitian ini adalah deskriptif statistik, uji asumsi klasik, analisis regresi linear berganda dan uji hipotesis.

Data yang akan dianalisa dari penelitian ini adalah :

$$
Y=\alpha+\beta_{1} X_{1}+\beta_{2} X_{1} * M+\beta_{3} X_{2}+\beta_{4} X_{3}+\beta_{5} X_{4}+\varepsilon
$$

Dimana:

Y : Tax Avoidance

$\alpha$ : Konstanta

$\beta 1$ - $\beta 6$ : Koefisien regresi variabel independen

M (moderasi) : Kepemilikan Institusional

$\mathrm{X} 1$ : Corporate Risk

$\mathrm{X} 2$ : Kepemilikan Institusional

X3 : Komisaris Independen

X4 : Kualitas Audit

e : Standar Error

\section{Rancangan Analisis dan Uji Hipotesis}

Analisis data mempunyai tujuan un tuk menyampaikan dan membatasi penemuan-penemuan hingga menjadi data yang teratur serta tersusun dan lebih berarti. Metode analisis menggunakan metode analisis data kuantitatif yang dinyatakan dengan angka-angka dan perhitungannya menggunakan program Eviews.

\section{Analisis Panel Data}

\section{Pemilihan Model pengolahan Data}

Pegolahan data dalam penelitian ini mempergunakan Eviews 9.0. Hal ini dilakukan agar hasil yang diperoleh menghasilkan dugaan yang efisien. Diagram pengujian statistic untuk memilih model yang efisien dapat digambarkan dalam table berikut :

\section{Uji Hipotesis}

Setelah model yang tepat diperoleh maka dilanjutkan dengan pengujian hipotesis. Uji hipotesis dilakukan untuk menentukan baik buruknya suatu model melalui uji kesesuaian (R2), uji secara bersama - sama koefisien regresi (uji F) maupun pengujian secara parsial (uji t), untuk menentukan diterima atau ditolaknya hipotesis.

\section{HASIL PENGUJIAN PENELITIAN}

Pada bab ini akan diuraikan hasil pengolahan data menggunakan software eviews 9.1 dengan jumlah individu 23 perusahaan dan periode waktu 3 tahun. 
Penelitian ini befokus pada corporate governance dan corporate risk sebagai variabel yang mempengaruhi tax avoidance perusahaan.

\section{Gambaran umum dan Sampel Penelitian}

Penelitian ini menggunakan sampel perusahaan yang terdaftar di Bursa efek Indonesia selama kurun waktu 2014 hingga 2016. Setelah memperoleh data perusahaan dibutuhkan, langkah selanjutnya adalah mengumpulkan data keuangan yang dibutuhkan melalui data stream dan laporan keuangan dari masing-masing perusahaan yang dijadikan sampel selama 3 tahun dari tahun 2014 sampai dengan tahun 2016, dengan jumlah keseluruhan yaitu 69 observasi.

\section{Pemilihan Model}

Penelitian ini menggunakan panel data, yaitu gabungan dari data cross section dan data time series sehingga jumlah pengamatan menjadi sangat banyak, oleh karena itu diperlukan teknik tersendiri dalam mengatasi model yang digunakan dalam menggunakan data panel (Nachrowi, 2006). Hasil pengujian hausman nilai probabilitas hausman testnya lebih besar dari 0.05 , yang menunjukkan bahwa $\mathrm{H} 0$ ditolak dan $\mathrm{H} 1$ diterima, model estimasi yang tepat untuk model ini adalah model random effect. Selanjutnya dilakukan Uji Lagrange Multiplier dimana analisis yang dilakukan dengan tujuan untuk menentukan metode yang terbaik dalam regresi data panel, apakah akan menggunakan common effect atau random effect. Pengujian yang dilakukan menunjukkan bahwa nilai $\mathrm{P}$ Value dibawah yaitu sebesar 0,000 dimana nilainya kurang dari 0,05. Sehingga Lagrange Multiplier Test ini menunjukkan bahwa metode estimasi terbaik adalah Random Effect.

\section{Uji asumsi klasik}

\section{Uji Normalitas}

Uji normalitas bertujuan untuk menguji apakah dalam model regresi panel variabel-variabelnya berdistribusi normal atau tidak. Model regresi yang baik adalah memiliki distribusi data normal atau mendekati normal.

Dalam software EViews normalitas sebuah data dapat diketahui dengan membandingkan nilai Jarque-Bera (JB) dan nilai Chi Square tabel. Uji JB didapat dari histogram normality dimana jika hasil dari JB hitung > Chi Square tabel data tidak berdistribusi normal. Dari hasil pengujian dengan eviews, di atas dapat dilihat bahwa model penelitian ini tidak mengalami permasalahan normalitas karena probabilitas dari Jarque-Bera sebesar 0,517743 (diatas 0.05).

\section{Uji Mutikolinearitas}

Uji multikolinearitas bertujuan untuk menguji apakah korelasi atau interkorelasi antar variabel independen (bebas) dalam model regresi. Hasil uji korelasi menunjukkan hubungan korelasi antar variabel independen berada dibawah 0,8 , yang menunjukkan bahwa tidak terjadi multikolinearitas antar variabel independen dalam persamaan regresi.

\section{3}




\section{Tabel 2 Uji Hipotesis}

Dependent Variable: Y

Method: Panel EGLS (Cross-section weights)

Sample: 20142016

Periods included: 3

Cross-sections included: 23

Total panel (balanced) observations: 69

Linear estimation after one-step weighting matrix

White cross-section standard errors \& covariance (d.f. corrected)

\begin{tabular}{crlrr}
\hline \hline Variable & Coefficient & Std. Error & t-Statistic & Prob. \\
\hline \hline C & 0.102606 & 0.018694 & 5.488729 & 0.0000 \\
X1 & 0.005286 & 0.004046 & 1.306399 & 0.1962 \\
LOGX2 & -0.034862 & 0.005613 & -6.210742 & 0.0000 \\
X3 & 0.101065 & 0.011713 & 8.628293 & 0.0000 \\
X4 & 0.105505 & 0.005443 & 19.38360 & 0.0000 \\
X5 & -0.005470 & 0.002606 & -2.099179 & 0.0398 \\
\hline \hline & Weighted Statistics & \\
\hline \hline R-squared & 0.242192 & Mean dependent var & 0.562945 \\
Adjusted R-squared & 0.182048 & S.D. dependent var & 0.419553 \\
S.E. of regression & 0.052976 & Sum squared resid & \\
F-statistic & 4.026894 & Durbin-Watson stat & 1.218806 \\
Prob(F-statistic) & 0.003108 & & \\
\hline \hline
\end{tabular}

Unweighted Statistics

\begin{tabular}{llll}
\hline \hline R-squared & 0.131656 & Mean dependent var & 0.260252 \\
Sum squared resid & 0.213021 & Durbin-Watson stat & 1.548676 \\
\hline \hline
\end{tabular}

*Signifikan pada level $1 \%$

** signifikan pada level $5 \%$

\section{Analisis Hasil Regresi}

Pengujian digunakan untuk menguji hipotesis dalam penelitian ini. menguji pengaruh corproate governance dan corporate risk terhadap tax avoidance yang diukur dengan ETR. Hasil pengujian diatas menunjukkan signifikansi model pada tingakt $1 \%$ dimana probabilitas dari statistik model adalah 0,003108 . R Square dari model penelitian ini adalah 0,242192 yang menunjukkan bahwa variabel bebas dalam penelitian ini mampu menjelaskan $24,22 \%$ variabel terikat. Dari hasil pengujian hipotesis, H1 dari penelitian ini tidak signifikan walaupun arah hubungan sesuai dengan prediksi, Risiko Perusahaan (Karakter eksekutif) berpengaruh positif terhadap Tax Avoidance. Namun, dengan dimoderasi oleh struktur kepemilikan institusional, corporate risk berpengaruh terhadap Tax Avoidance perusahaan. Hal tersebut ditunjukkan dalam hasil pengujian dengan

124 Chasbiandani ${ }^{1}$, Triastuti $^{2}$, Ambarwati $^{3}$


tingakt singikansi $1 \%$ yang menunjukkan bahwa H1a dalam penelitian ini terbukti.

Pengujian hipotesis lainnya terkait dengan pengaruh corporate governance yang diukur dengan struktur kepemilikan institusional, komisaris independen dan kualitas audit, berpengaruh terhadap tax avoidance perusahaan. Hasil pengujian regresi menunjukkan bahwa variabel bebas x3 signifikan pada tingakt $1 \%$. Arah hubungan sesuai dengan prediksi, yang berarti bahwa $\mathrm{H} 3$ dalam penelitian ini terbukti,Kepemilikan institusional berpengaruh negatif terhadap Tax Avoidance. Hal ini sejalan dengan penelitian yang dilakukan oleh Vidiyanna Rizal Putri, Bella Irwasyah Putra, (2017), Pengaruh Leverage, Profitability, Ukuran Perusahaan dan Proporsi Institusional terhadap Tax Avoidance yang menyatakan bahwa Proporsi kepemilikan institusioanal berpengaruh positif terhadap cash effective tax rate (CETR), semakin tinggi kepemilikan institusional maka semakin tinggi pula jumlah beban pajak yang harus dibayarkan dikarenakan semakin kecil kemungkinan praktik penghindaran pajak yang dilakukan oleh perusahaan.

Pengujian hipotesis keempat terkait dengan pengaruh komisaris independen terhadap tax avoidance. Dari hasil pengujian regresi, dapat dapat disimpulkan bahwa $\mathrm{H} 4$ dalam penelitian tidak terbukti, komisaris independen berpengaruh terhadap tax avoidance dengan tingkat signifikansi $1 \%$ namun arah hubungan justru positif. Hal tersebut sejalan dengan penilitian yang dilakukan Putra adan Merkusiwati (2016) yang menunjukkan bahwa Komisaris Independen dan Size berpengaruh positif dan signifikan pada tax avoidance artinya semakin tinggi jumlah komisaris independen dan semakin tinggi ukuran perusahaan maka tax avoidance akan semakin tinggi. Penelitian yang dilakukan oleh Wibawa et al (2016) juga menunjukkan hal yang sama, persentase dewan komisaris independen, berpengaruh positif terhadap penghidaran pajak perusahaan.

Hipotesis kelima dalam penelitian ini, berdasarkan hasil pengujian regresi terbukti dengan tingkat signifikansi 5\%. Arah hubungan sesuai dengan prediksi yang berarti bahwa kualitas audit berpengaruh negatif terhadap penghindaran pajak. Hal ini sejalan dengan penelitian yang dilakukan oleh Indrawan (2016) mengenai pengaruh Good Corporate Governace terhadap tax avoidance menunjukkan bahwa Good Corporate Governance yang diproksikan dengan indikator yaitu proporsi komisaris independen, komite audit, kualitas audit dan kepemilikan institusional berpengaruh negative terhadap penghindaran pajak BUMN. Penelitian yang dilakukan oleh Wibawa et al (2016) juga menunjukkan bahwa secara simultan persentase dewan komisaris independen, komite audit perusahaan, dan kualitas auditor eksternal berpengaruh secara signifikan terhadap penghindaran pajak, sedangkan secara parsial didapatkan persentase dewan komisaris independen dan komite audit perusahaan berpengaruh signifikan terhadap penghindaran pajak, dan kualitas auditor eksternal berpengaruh negatif dan tidak signifikan terhadap penghindaran pajak.

\section{PENUTUP}

\section{Kesimpulan}

Berdasarkan tujuan penelitian dan hasil yang diperoleh dalam penelitian ini maka dapat disimpulkan bahwa:

\section{5}


1. Secara simultan corporate risk dan corporate governance memiliki pengaruh signifikan terhadap tax avoidance perusahaan.

2. Risiko Perusahaan (Corporate Risk) tidak berpengaruh secara signifikan terhadap tax avoidance, namun bila dimoderasi dengan kepemilikan institusional, corporate risk berpengaruh signifikan terhadap tax avoidance perusahaan.

3. Kepemilikan institusional, komisaris independen dan kualitas audit, sebagai proksi dari corporate governance berpengaruh signifikan terhadap tax avoidance perusahaan.

\section{Keterbatasan dan Saran}

1. Penelitian ini baru mengkaji tax avoidance secara jangka pendek, Hendaknya untuk penelitian selanjutnya dapat membah periode penelitian dengan periode long run tax avoidance.

2. Penelitian ini hanya menggunakan kepemilikan insitusional, komisaris independen dan kualitas audit sebagai proksi dari corpoarte governance, padahal masih terdapat banyak proksi lain yang dapat digunakan sebagai proksi dari corporate governance, misalnya corporate governance indeks, proporsi komite audit, dan lain - lain.

3. Dalam penelitian ini, penggunaan corporate risk (risiko perusahaan) dianggap sebagai salah satu bentuk respon dari investor, dalam penelitian selanjutnya dapat digunakan pengukuran lain untuk menguji reaksi investor atas tax avoidance yang dilakukan oleh perusahaan, misalnya dengan Earning respon coefficient (ERC).

\section{DAFTAR PUSTAKA}

Adam C. H, (2002), Internal Organizasional Factos Influencing Corporate Social And Ethical Reporting Beyod Current Theorizing Accounting, Auditng andAccountability Journal Vol 14\5 No 2

Adinda Lionita H dan Ani Kusbandiyah (2017) dengan judul Pengaruh Corporate Social Responsibility, Profitabilitas, Leverage dan Komisaris Independen Terhadap Praktik Penghindaran Pajak Pada Perusahaan Yang Terdaftar di BEI, Kompartemen Vol. XV No 1, Maret 2017

Agung Wibawa, Wilopo, dan Yusri Abdillah (2016), Pengaruh Good Corporate Governance Terhadap Penghindaran Pajak (Studi Pada Perusahaan Terdaftar di Indeks Bursa Sri Kehati Tahun 2010-2014), Jurnal

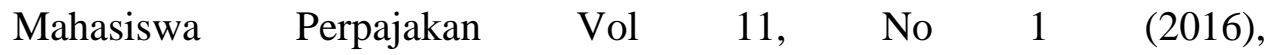
http://perpajakan.studentjounal.ub.ac.id

Ardyansyah dan Zulaikha (2014), Pengaruh Size, Leverage, Profitability, Capital Intensity Ratio dan Komisaris Independen Terhadap Effectivw Tax Rate (ETR) (Studi Empiris Pada Perusahaan Manufaktur Yang Terdaftar di BEI Selama Periode 2010-2012) 
Audina Gita Atami, Yesi Mutia Basri, Pipin Kurnia (2017), Pengaruh Corporate Governance, Manajemen Laba dan Capital Intensity Terhadap Agresivitas Pajak (Studi Kasus Pada Perusahaan Manufaktur Yang Terdaftar di BEI periode 2013-2015,Jurnal Online Mahasiswa, Universitas Riau, Vol 4 No 1, ISSN : 2355- 6854

Bursa Efek Indonesia.(2016). Laporan Tahunan.http://www.idx.co.id. Diakses 20 Desember 2017.

Christiana dan Fernando Africano (2017), Peran Corporate Governance Sebagai Pemoderasi Atas Pengaruh Agresivitas Pelaporan Keuangan Terhadap Agresivitas Pajak (Studi Empiris Perusahaan Manufaktur Yang Terdaftar Di Bursa Efek Indonesia Tahun 2012-2016), STMIK GI MDP, http://eprints.mdp.ac.id/id/eprint/2250

Dea Listika Sari, Deny Tristianto dan Rachmawati Meita Oktaviani (2016), Faktor-Faktor Yang Mempengaruhi Tax Avoidance Dengan Leverage Sebagai Variabel Mediasi

Deny Tristianto dan Rachmawati Meita Oktaviani (2016), Faktor-Faktor Yang Mempengiaruhi Tax Avoidance Dengan Leverage Sebagai Variabel Mediasi, Jurnal Dinamika Akuntansi Keuangan \& Perbankan, Vol 5

Edfan Daris, Meilda Wiguna (2017), Corporate Social Responsibility, Kepemilikan Mayoritas dan Corporate Governance Terhadap Agresivitas Pajak (Studi Pada Perusahaan Manufaktur Yang Terdaftar di BEI Tahun 2011-2014, Jurnal Online Mahasiswa, Universitas Riau, ISSN : 2355-6854

Deny Tristianto dan Rachmawati Meita Oktaviani (2016), Faktor-Faktor Yang Mempengaruhi Tax Avoidance Dengan Leverage Sebagai Variabel, Jurnal

Gusti Ayu Pradnyanita Dewi dan Maria M. Ratna Sari (2015) dengan judul Pengaruh Insentif Eksekutif, Corporate Risk Dan Corporate Governance Pada Tax Avoidance, E-Jurnal Akuntansi Universitas Udayana, Vol 13, No1 Oktober 2015

I Gusti Ln Ngr Dwi Cahyadi Putra dan Ni Ketut Lely Aryani Merkusiwati (2016), dengan judul Pengaruh Komisaris Independen, Leverage, Size dan Capital Intensity Ratio Pada Tax Avoidance, E-Jurnal Akuntansi Univeristas Udayana, Vol 17.1. Oktober (2016) : 690-714, ISSN : 23028556

Indrawan (2016), dengan judul Good Corporate Governace Dan Koneksi Politik Terhadap Penghindaran Pajak Pada Perusahaan BUMN Yang 
Terdaftar Di Bursa Efek Indonesi (BEI) Tahun 2010-2014, Thesis Universitas Airlangga

Kurniasih, Tommy dan Maria M. Ratna Sari, (2013), Pengaruh Return On Assets, Leverage, Corporate Governance, Ukuran Perusahaan dan Kompensasi Rugi Fiskal pada Tax Avoidance, Buletin Studi Ekonomi Vol 18, No 1. Hal 58-65

Latif Rahmawati (2017), Pengaruh Intensitas Modal, Sales Growth, Dan Karakter Eksekutif Terhadap Tax Avoidance Dengan Leverage Sebagai Variabel Intervening, Skripsi Universitas Muhammadiyah Yogyakarta

Ngadiman dan Christiany (2014), Pengaruh Leverage, Kepemilikan

Institusional, Dan Ukuran Perusahaan Terhadap Penghindaran Pajak (Tax Avoidance) Pada Perusahaan Sektor Manufaktur Yang

Terdaftar Di Bursa Efek Indonesia 2010-2012, Jurnal

Akuntansi/Volume XVIII, No 03 September 2014:408-421

Ni Putu Deiya Suprimarini dan Bambang Suprasto H (2017), Pengaruh Corporate Social Responsibility, Kualitas Audit, dan Kepemilikan Institusional pada Agresivitas Pajak, E Jurnal Akuntansi Universitas Udayana, ISSN 2302-85556, p 1349-1377

Nurul Hidayati, Fidiana (2017), Pengaruh Corporate Social Responsibility dan Good Corporate Governance Terhadap Penghindaran Pajak, Jurnal Ilmu dan Riset Akuntansi, Vol 6, Nomo 3 Maret 2017, ISSN : 2460-0585

Prakosa, K.B, (2014), Pengaruh Profitabilitas, Kepemilikan Keluarga, Corporate Governance Terhadap Penghindaran Pajak Di Indonesia, Proceeding Simposium Nasional Akuntansi XVII, Nusa Tenggara Barat 24-27 September 2014.

Puspitasari. Christiany dan Ngadiman (2014), Pengaruh Leverage, Kepemilihan Institusional dan Ukuran Perusahaan Terhadap Penghindaran Pajak (Tax Avoidance) Pada Perusahaan Sektor Manufaktur Yang Terdaftar di Bursa Efek Indonesia 2010-2012, Jurnal Akuntansi Volume XVIII, No 03:408-421

Syeldila Sandy dan Niki Lukviarman (2015), Pengaruh Corporate Governance Terhadap Tax Avoidance: Studi Empiris Pada Perusahaan Manufaktur, http://dx.doi.org/10.20885/jaai.vol19.iss2.art1

Swingly, Calvin dan I Made Sukarta (2015), Pengaruh Karakter Eksekutif, Komite Audit, Ukuran Perusahaan, Leverage dan Sales Growth Pada Tax Avoidance, E-Jurnal Akuntansi Universitas Udayana 10.1 (2015): Vol 47-62, ISSN : 2302-8556 
Vidiyanna Rizal Putri, Bella Irwasyah Putra, (2017), Pengaruh Leverage, Profitability, Ukuran Perusahaan dan Proporsi Institusional terhadap Tax Avoidance, DAYA SAING, Jurnal Ekonomi Manajemen Sumber Daya, Vol 19. No 1. Juni 2017 